\title{
NEED ANALYSIS FOR DEVELOPING COURSE BOOK FOR ENGLISH FOR ELEMENTARY SCHOOL STUDENTS WITH LOCAL-CONTENT VALUES
}

\author{
Devinta Puspita Ratri, Ika Puspitasari \\ Universitas Brawijaya Malang, Indonesia \\ (devinta@ub.ac.id)
}

Received: $20^{\text {th }}$ March 2019; Revised: $17^{\text {th }}$ May 2019; Accepted: $28^{\text {th }}$ June 2019

\begin{abstract}
The shifting of curriculum from School-based to curriculum of 2013 which has been regulated under the Government of the Republic of Indonesia's Regulation number 32 year 2013 about the alteration of Government Regulation number 19 year 2005 about National Standard of Education has some consequences in several factors. One of them is on the elimination of English subject in elementary school. Meanwhile, English is still badly needed in elementary school level. As a result, English is still offered in elementary school level but not as a subject. Instead, it is offered as a compulsory extra curricular for students. However, there was problem in its implementation which was caused by the different materials taught while the test administered was the same. As the consequence, the target for achievement could not meet the Minimum Mastery Criterion. It is even worse thatEnglish score becomes one of the requirements for enrolling in Junior High level. Thus, uniformity of syllabus and teaching materials for English subject for elementary school students is deemed necessary. Local values needs also to be embedded in the teaching materials to be developed as it is important in providing character education and reinforcing nasionalism for students. Prior to material development, a guideline for development is required. Thus, need analysis and local wisdom-based syllabus development for elementary school level becomes the focus for this research.
\end{abstract}

Key Words: Needs Analysis; teaching materials; local values

\section{ABSTRAK}

Perubahan kurikulum tingkat satuan pendidikan (KTSP) menjadi kurikulum 2013 untuk tingkat sekolah dasar berkonsekuensi pada berbagai faktor. Salah satunya adalah penghapusan mata pelajaran Bahasa Inggris pada tingkat sekolah dasar. Sedangkan permintaan masyarakat masih besar terhadap pembelajaran Bahasa Inggris di tingkat sekolah dasar. Dengan kondisi seperti sekarang ini, Bahasa Inggris tetap diberikan di tingkat sekolah dasar bukan sebagai mata pelajaran namun sebagai ekstra kulikuler wajib. Pada pelaksanaannya, timbul masalah karena tidak adanya keseragaman materi yang diberikan pada siswa padahal Bahasa Inggris diujikan di ujian sekolah. Sehingga target pencapaian Bahasa Inggris tidak bisa memenuhi Kriteria Ketuntasan Minimal (KKM). Ironisnya lagi, nilai Bahasa Inggris adalah sebagai salah satu syarat untuk masuk Sekolah Menengah Pertama. Maka dari itu, perlu adanya keseragaman silabus dan buku ajar Bahasa Inggris untuk sekolah dasar. Kearifan lokal juga dimasukkan dalam pengembangan buku ajar Bahasa Inggris untuk menanamkan pendidikan karakter dan penguatan rasa nasionalisme bagi peserta didik. Sebelum mengembangkan buku ajar, perlu ada acuan sebagai dasar pengembangan. Maka, dalam penelitian ini, dilaksanakan analisa kebutuhan dan pengembangan silabus untuk buku ajar berbasis kearifan lokal untuk sekolah dasar.

Kata Kunci: Analisa Kebutuhan; buku ajar; kearifan lokal

How to Cite: Ratri, D. P., Puspitasari, I. (2019). Need Analysis for Developing Course Book for English for Elementary School Students with Local-Content Values. IJEE (Indonesian Journal of English Education), 6(1), 1-9. doi:10.15408/ijee.v6i1.9908

IJEE (Indonesian Journal of English Education), 6 (1), 2019, 1-9

P-ISSN: 2356-1777, E-ISSN: 2443-0390 | DOI: http://doi.org/10.15408/ijee.v6i1.9908

This is an open access article under CC-BY-SA license (https://creativecommons.org/licenses/by-sa/4.0/) 


\section{INTRODUCTION}

The teaching of English in Indonesia has experienced dynamic changes from time to time. The policy concerning the teaching of English has been altered in accordance with the amendment of curriculum. The Regulation of the Government of the Republic of Indonesia number 32 year 2013 about the amendment of Government Regulation number 19 year 2005 about the National Standard of Education affirms that the increase in quality and competitiveness of human resource has become a national commitment. The National Mediumterm Plan 2010 - 2014 indicates that one of the substantial core of action program in education is the rearrangement of school curriculum in the attempt of producing competent students who are capable of fulfilling the needs for human resource required for national and local growth. The consequence of that particular government regulation is on the shifting curriculum from School-based Curriculum to curriculum 2013 which is believed to prepare young generation better to become more competitive in the future. Further, the components in the curriculum that are altered are regulated in ministerial regulation. The shifting from School-based Curiculum to Curriculum 2013, which was regulated in 2013, results in several issues. One of them is the omission of English subject in Elementary School. This can seen from the Ministry of Education Decree number 21 year 2016 about the content standard of primary and secondary education which excludes English from the subjects offered for elementary school students. The attachment accompanying it only mentions that English is offered for junior and senior high school students.

The reality in the field indicates that many English teachers have been recruited and many of them are civil servant. The omission of English for elementary school in curriculum 2013 has raised some effects. One of them is concerning the legal status for the teachers which further affects the process for certification and promotion. This is all because there is no slot for their expertise in elementary level of education. There are only three positions for teachers in elementary school,namely home teachers, physical education teachers, and religion teachers.

Another issue concerning the implementation of new curriculum is the omission of English subject from Elementary school. The government has come with its confirmation that the omission of English subject is for the reason that students do not really need 
English. It somehow contradicts the theory stating that language acquisition among young learners is better. Learning English for young learners is believed to improve confidence. Moreover, the main function of English is for communication. Young learners who master English will be more confident in communicationg with friends, teachers, or even people who are speaking English. This idea is somewhat in line with Vygotsky (1962) idea which states that in early childhood, language is used as a device to plan activities and solve problems. Thus, children taught English will tend to use it to get along with others and communicate to solve problems.

This government policy has caused complex problems for education in elementary level. Yet, due to high demand, English is still offered in elementary school as extracurricular subject. The complication adds up when English is still set as one of school subjects tested at school because the score of English becomes one of the requirement to be admitted at junior high school with the standard score of 70. This fact leaves many in question as to how the standard score can be achieved when there are no syllabus and materials available for teaching and learning process. So far, teachers of English in elementary schools used different books, handouts or students worksheets. Consequently, the materials taught vary from one school to another. It causes problem since the test of English in one paticular region is made the same. As the result, the test results are below expectation because the materials taught are not in line with the materials being tested.

This complex problem needs appropriate solutions which can affect many parties. One of the solutions is the development of appropriate English instructional materials to be used by all elementary schools so that the materials taught in schools are the same. Therefore, this research is aimed at initiating the development of instructional material for elementary school students by doing the needs analysis and syllabus development which would later be made as referrence in the instructional material development. The materials developed would be in the form of local valuesbased books. It is designed so as it wants to reject the notion that English subject can decrease students nationalism. Curriculum 2013 emphasizes character building and nationalism on students so that it might be the reason why English is excluded from the curriculum. Here, local values can be defined as "ideas or values, local or local view that is wise, full of wisdom, good-value embedded and 
followed by society" (Nurrahmawati, 2013).

Therefore, in purpose of integrating the local values in teaching English, it is expected that young learners who will be the next generation of this country can learn international language which is widely used and preserve their culture as well. Thus, English books developed based on local values are considered to be able to make elementary school students learn English while still possesing strong local character and without having to lose their nationalism.

Prior to the development of local value-based English book, the analysis of needs should be done yo map the appropriate materials for grade 1 to grade 6 students of elementary school. For this purpose, questionnaire was distributed to teachers in the effort of developing syllabus which are crucial for the book development later.

\section{METHOD}

This study employed research and development model formulated by Borg and Gall (1983) who state that this research design is a process done to develop and validate educational product. The steps taken are usually called as R \& D cycle which consists of needs analysis, product development based on the needs analysis, field testing in the real situation where the product will be used, and revision for the mistake found and shortage of the product identified during the field testing.

There are a total of ten stages in this design (Borg \& Gall, 1983). This first stage is information collection. This can be done in several different ways. Some of them are by library research and direct observation in the classroom. The second stage is identification of learning objective. Then, it is followed by initial product development. Meanwhile, the fourth stage is initial field testing. For this need, some instruments such as questionnaire, interview guideline, and/or observation sheet will be required. The fifth stage is the product revision done based on the suggestion from the intial field testing. The next stage is main field testing which is followed by product revision. The last stage is product dissemination and implementation. It can be done by writing journal article, attending seminar, or by publishing the product.

\section{Data Source and Data Collection Technique}

This research involved data which was taken from the following research instruments: 


\section{Needs Analysis}

For needs analysis, instrument used was questionnairre that was distributed to 23 elementary school teachers. This instrument was intended to collect information about the things needed to develop the English syllabus.

\section{Expert Validation}

Some experts were involved to ensure that the syllabus developed were in line with the existing objectives. Those experts validated the content of syllabus by referring to principles of local values. In this stage, the instruments required were checklist and interview.

\section{Try-out}

In this try-out stage, the developed syllabus was directly applied by developing samples of the materials. This was done in order to reflect the feasibility of the syllabus to be later fully developed into books. In this try-out stage, the instrument used was checklist for the material samples developed.

\section{FINDINGS AND DISCUSSION}

\section{Findings}

A questionnaire was distributed to 23 English teachers who are teaching at elementary school seeking need analysis toward syllabus and textbook with local values. From the questionnaire distributed to English teachers in Batu, it revealed that all teachers responded that syllabus has important role as guidance in teaching English. Talking about the importance of syllabus, the questionnaire surveyed whether there is syllabus for English course for elementary schools. $40 \%$ respondents said that there is syllabus a guidance for teachers to teach English, but $60 \%$ of them mentioned that there is no syllabus to be referred to. Further, those who said that there is no syllabus for English course argued that it is needed to develop syllabus. About the syllabus with local values, most respondents, $64 \%$ of the population, said that they are familiar with it; and $36 \%$ of them said that they do not know about syllabus with local values. However, all of them agree if syllabus is developed with local values.

Next, about the method that is suitable to be implemented for teaching young learners at elementary schools (respondents can choose more than one option), 13 respondents chose cooperative learning, 8 respondents selected communicative teaching, 10 respondents mentioned task based learning, and 12 respondents prefered total physical response, and 5 respondents mentioned other method, they are: Contextual Teaching Learning, 
Topical Syllabus, Content Based Learning, Integrated/Mix Method. About the appropriate materials for elementary students (respondents can select more than one option), 8 respondents chose grammar, 9 respondents chose general English, 21 respondents selected text with local values 13 respondents chose conversation, and 2 respondents selected building vocabulary. Next, about the existence of English course book, $87 \%$ of respondents mentioned yes and 13\% Respondents said no. A confirmation toward the existence of English textbook done by interviewing the head of English teacher association; she argued that English teachers used different textbooks with different materials, therefore, it is difficult for them to measure students ability in English when they graduate from elementary schools as they learn different materials. Responding to this phenomena, the head of English teacher association pushed the development of syllabus and textbook. Further question in the questionnaire asking about the need of developing English course book, all of the respondents said yes and they agree of developing course book with local values.

From the survey, it can be drawn a conclusion that syllabus is highly needed by English teachers as guidance in the teaching and learning process since there is no fixed syllabus for teaching English at elementary school. Hence, the development of syllabus becomes the top demand to cope the problem of vacillating in what to teach in English class. Bourke (2006) states that developing syllabus outline the mismatches that may occur between teachers and learners in three important domains: a) the experiential domain, b) the learning process domain, and c) the language content domain. Further, local values needs to be added in the syllabus as a reference topic.

To be specific, in developing syllabus, teaching method is substantial to be brought. Appropriate English teaching method propounded by English teachers are cooperative learning, communicative teaching, taskbased learning, total physical response, contextual teaching, content based learning, integrated/mix method. Hudelson (1991) discloses four basic principles of learning and language learning that are embedded in a topicbased/task-based approach: 1 Young learners are in the 'concrete operations' stage of cognitive development. This means that they learn through handson experiences. It follows that in language classes children 'need to be active rather than passive; they need to be engaged in activities of which language is a part; they need to be working on meaningful tasks and use 
language to accomplish those tasks'. 2 In a group situation some members know more than others. Those who know less can learn from those who know more. Hence, children need to interact with and learn from each other. Teachers too need to interact with the children in order to challenge them to go beyond their present level of expression. This kind of contextual support is known as 'scaffolding' (Ellis,1997). 3 Acquisition is a discovery process. Learners have to figure out how the language works. 'In terms of the classroom context, an implication is that learners need opportunities to use and to experiment with the new language.' . Learners must be free to make errors so they can re-structure their emerging language system. 4 Acquisition occurs through social interaction. Meaning is constructed jointly as learners work together and exchange messages. They need to talk to each other in order to negotiate meaning.

In addition, English teachers suggest grammar, general English, text with local values, conversation, and vocabulary to be considered as materials in teaching young learners. Tomlinson (2001) argues that materials development is both a field of study and a practical undertaking. As a field, it studies the principles and procedures of the designed, implementation and evaluation of language teaching materials. As a practical undertaking, it refers to anything which is done by writers, teacher or learners to provide source of language input, to exploit those source in ways which maximise the likelihood of intake and to stimulate purposeful output. Further, following to the English syllabus, English course book with local wisdom also need to be developed. In accordance, Septy (2016) mentions that cultural awareness/understanding may become an important issue in English communicative competence. The ability to communicate should not disregard character values that are generated from cultural values, and this could be a determining resource in improving students' English proficiency. Besides, this cultural resource could relate to the process of character building. Therefore, the culturally based resources have to be considered in selecting teaching-learning materials. Then, lessons from local wisdoms, in particular, may be taken from the meaning of local legends, folklores, special places in the village, certain traditional/monumental objects, building, rivers, mount/hill, forest, and the like. The lessons from local wisdom may contain particular meaning of norms and values to understand.

Prior to the syllabus development, the topics for each grade are set by 
teachers of elementary school in Batu. The topics set are based on in the Peraturan Menteri Pendidikan Nasional number 57 year 2014 about Elementary School Curriculum.

\begin{tabular}{|c|c|c|}
\hline 1st GRADE & 2nd GRADE & 3rd GRADE \\
\hline $\begin{array}{l}\text { Myself } \\
\text { Greeting and } \\
\text { Introduction } \\
\text { integrating } \\
\text { Indonesian } \\
\text { politeness }\end{array}$ & $\begin{array}{l}\text { Living } \\
\text { Harmoniously } \\
\text { Gotong royong }\end{array}$ & $\begin{array}{l}\text { Animals and } \\
\text { Plants } \\
\text { Reproduction } \\
\text { Tending animals } \\
\text { and plants }\end{array}$ \\
\hline $\begin{array}{l}\text { My Hobby } \\
\text { Layang-layang }\end{array}$ & $\begin{array}{l}\text { Lets Play } \\
\text { Playing at } \\
\text { playground }\end{array}$ & $\begin{array}{l}\text { Technology } \\
\text { Using } \\
\text { smartphone } \\
\text { wisely }\end{array}$ \\
\hline My Activity & My Chores & Natural Change \\
\hline $\begin{array}{l}\text { Helping } \\
\text { parents }\end{array}$ & Baby sitting & $\begin{array}{l}\text { Climate in } \\
\text { Indonesia }\end{array}$ \\
\hline $\begin{array}{l}\text { My Family } \\
\text { Family tree }\end{array}$ & $\begin{array}{l}\text { I love My } \\
\text { School } \\
\text { Flag ceremony }\end{array}$ & $\begin{array}{l}\text { Environment } \\
\text { Care } \\
\text { Less plactics }\end{array}$ \\
\hline My Experience & Healthy Life & Traditional \\
\hline $\begin{array}{l}\text { Visiting } \\
\text { grandma }\end{array}$ & Doing exercise & $\begin{array}{l}\text { Games } \\
\text { Gobak sodor, } \\
\text { jumpritan }\end{array}$ \\
\hline $\begin{array}{l}\text { Healthy } \\
\text { environment } \\
\text { Go green }\end{array}$ & $\begin{array}{l}\text { Water, Earth } \\
\text { and Sun } \\
\text { Season in } \\
\text { Indonesia }\end{array}$ & $\begin{array}{l}\text { Friendship } \\
\text { Honesty }\end{array}$ \\
\hline $\begin{array}{l}\text { My } \\
\text { environment } \\
\text { Pets in } \\
\text { Indonesia }\end{array}$ & $\begin{array}{l}\text { Animals and } \\
\text { Plants } \\
\text { Animals and } \\
\text { plants in } \\
\text { Indonesia }\end{array}$ & $\begin{array}{l}\text { Energy } \\
\text { Save energy }\end{array}$ \\
\hline $\begin{array}{l}\text { Natural } \\
\text { Phenomena } \\
\text { Weather in } \\
\text { Indonesia }\end{array}$ & $\begin{array}{l}\text { Safety } \\
\text { Travel safety }\end{array}$ & $\begin{array}{l}\text { Earth and } \\
\text { Universe } \\
\text { Save our earth }\end{array}$ \\
\hline 4th GRADE & 5th GRADE & 6th GRADE \\
\hline $\begin{array}{l}\text { Togetherness } \\
\text { Selametan }\end{array}$ & $\begin{array}{l}\text { Things around } \\
\text { Eco green park }\end{array}$ & $\begin{array}{l}\text { Reforestation } \\
\text { Don't litter }\end{array}$ \\
\hline $\begin{array}{l}\text { Energy } \\
\text { Conservation } \\
\text { Save water }\end{array}$ & $\begin{array}{l}\text { Events in Life } \\
\text { Birthday }\end{array}$ & $\begin{array}{l}\text { Unity in Diversity } \\
\text { Bhineka tunggal } \\
\text { ika }\end{array}$ \\
\hline $\begin{array}{l}\text { Environmental } \\
\text { Care }\end{array}$ & $\begin{array}{l}\text { Me and } \\
\text { Society }\end{array}$ & $\begin{array}{l}\text { Invetors } \\
\text { Invetor of padi }\end{array}$ \\
\hline $\begin{array}{l}\text { Use reusable } \\
\text { straw } \\
\text { Bring your } \\
\text { own bottle }\end{array}$ & Courtesy & Gogo \\
\hline $\begin{array}{l}\text { Profession } \\
\text { Farmer }\end{array}$ & $\begin{array}{l}\text { Health } \\
\text { Go to dentits }\end{array}$ & $\begin{array}{l}\text { Globalization } \\
\text { Sending Email }\end{array}$ \\
\hline
\end{tabular}

\begin{tabular}{|c|c|c|}
\hline & $\begin{array}{l}\text { every } \\
\text { months }\end{array}$ & \\
\hline & Nationalism & Entrepreneurship \\
\hline $\begin{array}{l}\text { irtini, } \\
\text { ponegoro }\end{array}$ & $\begin{array}{l}\begin{array}{l}\text { Iracaronal } \\
\text { clothes }\end{array} \\
\text { a }\end{array}$ & Pers \\
\hline & & \\
\hline & & \\
\hline 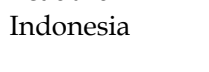 & & \\
\hline & Indon & \\
\hline pur guid & History & favorite \\
\hline & $\begin{array}{l}\text { The origin of } \\
\text { Batu }\end{array}$ & teacher \\
\hline & & \\
\hline & Tropic & $\mathrm{Cli}$ \\
\hline Ealthy Food & & \\
\hline $\begin{array}{l}\text { Bring your } \\
\text { lunchbox }\end{array}$ & $\begin{array}{l}\text { Environment } \\
\text { Emphaty, } \\
\text { Sympathy }\end{array}$ & \\
\hline \multicolumn{3}{|c|}{$\begin{array}{l}\text { Table 1. Topics and sub topics set } \\
\text { or English subject for elementary } \\
\text { chool }\end{array}$} \\
\hline \multicolumn{3}{|c|}{$\begin{array}{l}\text { This topics will be developed into } \\
\text { set of English instruction in the form of } \\
\text { syllabus that later on become a } \\
\text { guidance for teachers in teaching } \\
\text { English subject at Elementary Schools. }\end{array}$} \\
\hline
\end{tabular}

\section{CONCLUSION}

English language teaching could be suspected to open access for foreign cultures to infiltrate. This situation may create conflict with local/national cultures and values/norms of Indonesia. In spite of this, it all depends on how English language teaching is viewed in the framework of national development. Obviously, having English proficiency offers an opportunity for Indonesians to take part in the international competition. 
As well, students are potential to develop their competitive power through which they could demonstrate their English proficiency. The most important thing to take into account is how they keep maintaining their identity and integrity reflected in their characters as well as their spirit nationalism. This relies on the development of English syllabus based on local values which is worth conducting because of the absence of English syllabus for Elementary school. Therefore, the development of syllabus with local values is urgently needed which is done in this research. Futhermore, the development of English textbook with local values based on the syllabus which was developed is worth conducted for the next research in contributing good English teaching and learning process without setting aside Indonesians students' core culture and values.

\section{REFERENCES}

Borg, W.R \& Gall, M.D. 1983. Educational Research: An Introduction. New York: Longman

Bourke, J.M. (2006). Designing a topicbased syllabus for young learners. ELT Journal Volume 60/3 July 2006.

Ellis, R. 1997. Second Language Acquisition. Oxford: Oxford University Press.

Hudelson, S. 1991. 'EFL teaching and children: a topic-based approach'.
English Teaching Forum October 1991.

Nurrahmawati, Farida. 2013. Strategi komunikasi pemberdayaan ekonomi perempuan Madura berbasis kearifan lokal Madura. Jurnal Komunikasi Vol. VII No 1 Maret 2013:1-67 ISSN 1978-4597.

Peraturan Menteri Pendidikan dan Kebudayaan nomor 21 tahun 2016 tentang standar isi pendidikan dasar dan menengah

Peraturan Pemerintah Republik Indonesia Nomor 32 Tahun 2013 Tentang Perubahan Atas Peraturan Pemerintah Nomor 19 Tahun 2005 Tentang Standar Nasional Pendidikan

Peraturan Menteri Pendidikan Nasional Nomor 57 Tahun 2014 tentang Kurikulum Sekolah Dasar

Septy, A.P. (2016). Managing Local Wisdom in English Teaching Materials. Proceedings of ISELT FBS Universitas Negeri Padang Vol 4 No 1

Tomlinson, B. (2011). Materials Development in Language Teaching. United Kingdom: Cambridge University Press.

Vygotsky, L. S. (1986). Thought and language. Cambridge, MA: MIT Press. 